\title{
Village Owned Enterprises (BUMDEs) Social Entrepreneurship Innovation in developing the Potential of Local Wisdom (Case Study on BUMDEs Cisantana, Kuningan Regency)
}

\author{
Iyan Setiawan ${ }^{1 *}$, Disman $^{2}$, Sapriya $^{3}$, Elly Malihah ${ }^{4}$ \\ ${ }^{1}$ Post Graduate Student in Economic Education, Faculty of Teacher Training and Education Universitas \\ Kuningan, Indonesia, ${ }^{2}$ Economy Education of Faculty of Social Studies Education, Universitas \\ Pendidikan Indonesia, Indonesia, ${ }^{3}$ Civic Education, Faculty of Social Studies Education, Universitas \\ Pendidikan Indonesia, Indonesia, ${ }^{4}$ Sociology Education, Faculty of Social Studies Education, Universitas \\ Pendidikan Indonesia, Indonesia
}

\{iyan.setiawan@uniku.ac.id\}

\begin{abstract}
Social entrepreneurship is the process of building residents or transforming institutions to improve solutions to village social problems by developing Village Owned Enterprises (BUMDEs) to be managed in bringing changes towards welfare and increased community economic independence. The objectives of Village Owned Enterprises (BUMDEs) include increasing community economic income and village economic growth. The problem that occurs is from the author's observations from several Bumdes, the existence of Bumdes in its activities has not yet developed the village's original potential as a village advantage that can be developed. Social innovation offers solutions to social, economic, environmental problems and opens up space for the community to be creative in generating regional benefits. In the village there is a lot of natural potential, local village products can be better and be able to increase community income. This paper attempts to provide a literature review of the concept of social entrepreneurship, Village Owned Enterprises (BUMDEs) and social innovation. The research method used is library research / literature study and data analysis techniques. This technique analyzes the content of the discussion in depth on written information. The role of BUMDEz Social Entrepreneurship in building Village Social Innovation will form a mindset, attitude and behavior that can be developed in practice and community action. By strengthening the professionalism of the BUMDEs management team, it will be able to encourage community businesses in the village and build social entrepreneurship through exploring the local potential / local potential, so as to build economic independence for rural communities
\end{abstract}

Keywords: Social Entrepreneurship; Bumdes and Village Social Innovation;

\section{Introduction}

Indonesia is a country with a large population and a significant growth rate. However, the rate of population growth is not directly proportional to the welfare of the community. This resulted in Indonesia experiencing various unemployment problems because the large workforce was not proportional to the number of available jobs. The high unemployment rate of course can cause social problems, namely poverty and social inequality. This requires several concrete solutions that emphasize the social problems that arise due to high levels of 
unemployment because limited employment opportunities. One of the ways to overcome unemployment and improve the Indonesian economy is to increase the entrepreneurial interest of the younger generation. The state can prosper if at least $2 \%$ of the population becomes entrepreneurs [1] in [2]. In the last few years, entrepreneurship has developed not only to seek profit but to have a positive impact on the social goals of society which is currently known as social entrepreneurship.

Social entrepreneurship is the use of entrepreneurial behavior that is more oriented towards the achievement of social goals and does not prioritize profit gains, or the profits obtained are used for social interests [3]. The problems that occur from the observations of the authors from several Bumdes are that the existence of Bumdes has not yet developed the village's original potential as regional excellence that can be developed independently. For this reason, social innovation is needed that is able to overcome social, economic, and environmental problems and open up space for the community to be creative in generating regional benefits. In the village there is a lot of natural potential, local village products can be better and be able to increase community income.

Innovation is an important element in social entrepreneurship [4]. The existence of Bumdes certainly has the potential for excellence of each region to be developed, but the problem is that many village administrators and community do not realize the potential benefits that the village has. In the village there is a lot of natural potential, the village's local products can be better and be able to boost local income. Bumdes should be responsive in developing social enterprises as village institutions and ensure that all citizens feel the benefits as a locomotive for improving community welfare through changes in social innovation.

Changes in the village that are driven by social innovation can be seen in dimensions referring to the form of social processes that occur, awareness of social processes in the community, and the forces that drive the process [6]. Social processes are related to the stages taken to achieve these changes. The results of social change are closely related to the impact of the changes, be they cultural or structural changes. Awareness of social processes is closely related to how the motive for the emergence of awareness to bring about social change. This will also be closely related to what forces drive social change. This change sees the source of social change is born out of the debate of experts about the role of individual agents and collective agents Sztompka [6]. In the context of the village as a socio-economic institution, entrepreneurship which contributes to the birth of agents of social change, one's involvement in educational activities brings closer involvement in social change [7]. Based on the description above, this study aims to analyze and identify the role of Village Owned Enterprises (BUMDEs) Social Entrepreneurship in developing Social Innovation.

\section{Literature Review}

\subsection{Social Entrepreneurship}

Entrepreneur is someone who establishes and runs an innovative business [8]. Then the term entrepreneurship is basically a discipline that studies a person's values, abilities and behavior in dealing with life challenges to obtain opportunities with various risks that may be faced. In conclusion entrepreneurship is all things related to the attitudes, actions and processes undertaken by entrepreneurs in starting, running and developing their business. The growing development of entrepreneurship when it appears about Social Entrepreneurship. Social entrepreneurship marks the need to encourage social change in society to produce 
sustainable, beneficial transformations. When economic conditions experience a downturn, when there are groups of people who experience conditions of poverty, powerless to overcome poverty, high unemployment, many beggars, thugs and vagrants are classified as poor, it becomes the duty of everyone who is able to help the weak. Research results entrepreneurial behavior has a positive and significant effect on business development [22]. So that the emergence of social entrepreneurship is important as a way out for the community itself.

Social entrepreneurship can be defined as "the creation of social value that is produced in collaboration with people and organization from the civil society who are engaged in social innovation that usually imply an economic activity". [4]. The comprehensive definition above provides an understanding that social entrepreneurship consists of four main elements, namely social value, civil society, innovation, and economic activity: [4] To find out from social entrepreneurial behavior, use Theory of Planned Behavior. Theory of Planned Behavior states that a person's intention to carry out a behavior, intention is an intermediate variable that causes the behavior of an attitude or other variables [9].

From the explanation above, entrepreneurship is currently developing into social entrepreneurship because of the public's awareness of social goals and not prioritizing solely learning profits or profits being used for social interests, then social entrepreneurship emerges. Look at previous research explaining social entrepreneurial behavior and skills, leadership skills that must be developed by social entrepreneurs, how to act innovatively by making changes for the welfare of society.

\subsection{Village Social Innovation}

Regional Government Regulation No. 38 of 2017 concerning Regional Innovation (Article 2 Paragraph 1 of PP No. 38 of 2017) according to this PP the target is directed to accelerate the realization of community welfare through improving public services, empowerment, community participation in increasing regional competitiveness. With the existence of this Regional Government Regulation the Head of Bumdes must understand, accept and take advantage of Bumdes social innovations by encouraging the community to be actively involved in achieving social goals. Innovation occurs because of feelings of dissatisfaction with existing conditions and situations as well as opportunities to improve existing conditions, innovation must be used as a tool and not a goal. The goal of an innovation is a change or improvement from existing conditions to be better, but not all changes can be said to be an innovation (Saiman, 2011).

In this study, entrepreneurial behavior is conceptualized as a person's actions which include innovativeness [21]. Social innovation is closely related to social entrepreneurship. Social innovation is the foundation for a social entrepreneur in running a business or activities to seek opportunities, improve systems, find new approaches and create solutions to better environmental changes [12]. A social entrepreneur looks for innovative ways to ensure that his business will have access to the resources needed as long as they can create social value [13].

On the other hand, social innovation is not limited to welfare issues but may also be related to environmental protection and sustainable development issues (in relation to corporations, one of the "forms" of social entrepreneurship that exists in an organization is the implementation of a corporate social responsibility program).

The results of the study concluded that innovative ideas combining social and business concepts and taking advantage of entrepreneurial opportunities provide hope for efforts to solve social problems. Social innovation is an idea or new idea that must be understood and applied to solve social problems and improve social welfare. Hadi Bagus Sektiawan and J Jamaluddin [17]. 


\subsection{Local Wisdom}

Local wisdom consists of two words, namely wisdom and local. The definition of local wisdom means local wisdom which can be understood as local ideas that are wise, full of wisdom, of valuable values that are embedded and followed by the members of the community. In the concept of anthropology, local wisdom is also known as local knowledge (indigenous or local knowledge), or the ability of local communities to select foreign cultures that are adapted to local culture (local genius) which is the basis of cultural identity. Local wisdom can be said to be all forms of knowledge, belief, understanding or insight as well as customs or ethics that guide human behavior in life in an ecological community. All forms of local wisdom are lived, practiced, taught and passed on from generation to generation as well as forming patterns of human behavior towards fellow humans, natural and occult [14].

It can be understood, in adapting to the environment, the community obtains and develops wisdom in the form of knowledge or ideas, customary norms, cultural values, activities, and equipment as a result of the abstraction of managing the environment. Often their knowledge of the local environment is used as an accurate guide in developing life in their neighborhood [15]. The results of research on entrepreneurial knowledge affect motivation (21). With knowledge, of course, will motivate to develop the potential of local wisdom in the area. Local wisdom is important to be preserved in the community in order to maintain balance with the environment while preserving the environment.

Local wisdom is important to be preserved in a community in order to maintain balance with the environment and at the same time preserve the environment. The development of local wisdom cannot be separated from the influence of various factors that will influence human behavior towards their environment. So the scope of local wisdom is very broad and holistic depending on what perspective is used in looking at local wisdom itself. Basically, local wisdom cannot be separated from human interaction with the environment which is developed because it is considered still relevant to the life of the local community.

\section{Methodology}

The research method used in this writing is a qualitative method. This study uses a qualitative approach through observation with an understanding of meaning, this method is used to explore meaning that comes from social problems. [20]. Qualitative methods are research that intends to understand the phenomena experienced by research subjects such as behavior, perception, motivation, actions etc. Then the data collection technique used is through literature review from several literature sources in looking at the problems studied.

\section{Result and Discussion}

The existence of bumdes certainly has the potential for excellence of their respective regions to be developed, but the problem is that there are still village government officials and administrators who have not realized the potential that the region has. Area development is a real solution to be carried out in attracting visiting tourists, as has been done by BUMDes Cisantana, Cigugur District, Kuningan Regency. The development of the Bumdes Cisantana business unit can be used as a reference, including the Sukageuri View Tourism Business Unit, which is the result of the reclamation and arrangement of ex-excavation land $\mathrm{C}$ covering 
an area of 5 hectares, the Service and Trade Business unit: a). LPG gas sales partnership with the Kuningan region gas distributor b). Partnership in financial services with banks (BJB and BRI), c) Become an agent of BPJS Ketenagakerjaan (Perisai) d). Helping to market community products such as Jasuci, Sambal Puluruk, Gemblong, Sweet Potato Chips etc. (Source: Bumdes Cisantana).

This strategic step ensures that all citizens feel the benefits of it as a locomotive for improving social welfare through social innovation. The role of Village Owned Enterprises (BUMDEs) which is managed by the management must be able to bring change to the community and find new solutions to overcome problems that occur, when thought of in new ways and creative ideas will result in new breakthroughs in creating new opportunities so that they have a product that is of value to use as happened at Bumdes Cisantana. Community empowerment in the absorption of labor for the Sukageuri View area, Cisantana Park, Curug in Sawer, Pamdes and Trade has reached 121 people (Source Doc. Bumdes Cisaantana)

This provides an explanation that Bumdes should focus on social innovation. Social innovation is the creation of real and useful social benefits for the community and the surrounding environment. The key to social entrepreneurship is social innovation (Bill Drayton, 2006). Furthermore, the research results conclude that social entrepreneurship plays a real and important role in solving social problems. Social value creation and innovation are the main instruments in social entrepreneurship [17].

Social innovation has the following criteria: 1) overcoming social problems, 2) creating new institutional relationships (collaboration), 3) increasing capacity, 4) increasing welfare, and 5) sustainability [18]. Based on data obtained by researchers in the field, the development of the tourist area of Cisantana Village is the criteria for social innovation that has developed the potential of the area by overcoming social problems in the community. Increasing the welfare of the community, social innovation aims to increase the quantity and quality of community life [19]. The effects of social innovation go beyond meeting needs, social innovation can increase the capacity and welfare of society [18].

\section{Conclusion}

Bumdes must explore the potential of village wisdom as an advantage in making changes in social innovation, as has been done by Bumdes Cisantana. Opening of tourist areas as a solution to change, is accelerated and directed in improving the welfare of the community; 2) This strategic step of social innovation ensures that all citizens feel its benefits as a locomotive for improving community welfare. 3) Village Owned Enterprises (BUMDEs) must focus on social innovation, namely the creation of real and useful social benefits for the community and the surrounding environment. 5). the key in social entrepreneurship is social innovation 4). Bumdes maintains sustainability and collaborates with all stakeholders.

\section{References}

[1] Mc.Clelland, (1967). The Achieving Society. New York: The Free Press.

[2] Santi, Nur \& Hamzah, Amir \& Rahmawati, Teti. 2017. Pengaruh Efikasi Diri, Norma Subjektif, Sikap Berperilaku, dan Pendidikan Kewirausahaan Terhadap Intensi Berwirausaha. Jurnal Inspirasi Bisnis Dan Manajemen, Vol 1, (1), 2017, 63-74 E-2579-9401, P-2579-9312. 
[3] Utomo (2014:2). Menumbuhkan Minat Kewirausahaan Sosial. Among Makarti, Vol.7 No.14.

[4] Hulgard. Lars (2010). Discourses of Social Entrepreneurship-Variation of The Same Theme?EMES European Research Network

[5] Ahmad Soleh . Strategi Pengembangan Potensi Desa. Jurnal Sungkai. Vol.5 No.1, Edisi Februari $2017 \mathrm{Hal}: 32-52$

[6] Sztompka, Piotr. (1993). Sosiologi perubahan sosial. Jakarta : Prenada

[7] Brown, Michelle and Beate Baltes. 2017. "The Relationship Between Social Change Involvement and Education". Journal of Social Change. Vol. 9 Issue 1: 131-140;doi: 10.5590/JOSC.2017.09.1.13

[8] Andrew J. Dubrin (2008) dalam Gusti (2017:135). Kewirausahaan Sosial Dalam Meningkatkan Kemampuan Enterpreneur Pada Mahasiswa Pendidikan Luar Sekolah Untuk Menghadapi Abad 21. Seminar Nasional Pendidikan Nonformal FKIP Universitas Bengkulu, Vol 1 Nomor 1.

[9] Ajzen, I. (1991). The Theory Of Planned Behavior. Organizational Behavior Human Decision Processes, 50 (2),179-211. https:// doi.org /10.1016/ 07495978 (91)90020-T

[10] Peraturan Pemerintah Daerah No.38 Tahun 2017 tentang Inovasi Daerah (Pasal 2 Ayat 1 PP No. 38 Tahun 2017)

[11] Saiman, Marwoto, 2011, "Inovasi Metode Pembelajaran Sejarah", Jurnal Ilmu-Ilmu Sejarah, Budaya dan Sosial.

[12] Widiastusy, Ratna dan Meily Margaretha, 2011, "Socio Entrepreneurship : Tinjauan Teori dan Perannya Bagi Masyarakat", Jurnal Manajemen Universitas Kristen Maranatha.

[13] Mort, Gillian Sullivan \& Jay Weerawardena, 2003, Social entrepreneurship: towards conceptualisation, International Journal of Nonprofit and Voluntary Sector Marketing.

[14] Keraf, Sonny. A. (2002). Etika Lingkungan. Jakarta: Penerbit Buku Kompas, PT. Kompas Media Nusantara.

[15] Suhartini. 2009. Kajian Kearifal Lokal Masyarakat Dalam Pengelolaan Sumber Daya Alam dan Lingkungan.Prosiding Seminar Nasional Penelitian, Pendidikan dan Penerapan MIPA. Fakultas MIPA-Universitas Negeri Yogyakarta. Yogyakarta.

[16] Drayton, B. \& Falk, J.K. (2006).Tell-Tale Signs of Inquiry-Oriented Classrom. NASSP Bulletin, 85 (623),23-34.

[17] Hadi Bagus Sektiawan Dan J Jamaaluddin (2018). Pengaruh Pelatihan Kewirausahaan Untuk Pengentasan Kemiskinan Melalui Pendekatan Kewirausahaan Sosial Sebagai Penopang Kemajuan Bangsa. IOP Conf. Series: Materials Science and Enginering Conference (AASEC) IOP Publishing. Surabaya

[18] Moulaert, Frank, Martinelli, F., Swyngedouw E., dan Gonzalez Sara (2010). Social Innovation and Community Development. London: Rotledge Taylor \& Francis Group, London.

[19] Jali, Muhammad Nizam, Zakaria Abas, dan Ahmad Shabudin (2016). Soial Innovation: A New Paradigm of Innovation Outcome Strategi in the context of Strategic Knowledge Management Processes. Malaysia: UTM Press

[20] Jali, Muhammad Nizam, Zakaria Abas, dan Ahmad Shabudin (2016). Soial Innovation: A New Paradigm of Innovation Outcome Strategi in the context of Strategic Knowledge Management Processes. Malaysia: UTM Press

[21] Cresweel, (2014). Research Design Kualitatif, Kuantitatif and Mixed (Third). Pendekatan. Pustaka Pelajar. Yogyakarta

[22] Iskandar (2020). Jurnal Penelitian Pendidikan dan Ekonomip. Equilibrium: -ISSN 0216-5287, eISSN 2614-5839 Volume 15, Issue 02

[23] Pupu Saeful Rahmat, (2020). Jurnal Penelitian Pendidikan dan Ekonomip. Equilibrium: -ISSN 0216-5287, e-ISSN 2614-5839 Volume 17, Issue 1

[24] Cucu Suhartini (2020). Jurnal Penelitian Pendidikan dan Ekonomip. Equilibrium: -ISSN 0216-5287, e-ISSN 2614-5839 Volume 17, Issue 02 